\title{
IMPLEMENTASI TEKNOLOGI NFC UNTUK RECORDING DATA SAPI PERAH KELOMPOK TANI LEMBU ALAM SERAMBI KOTA PADANG PANJANG
}

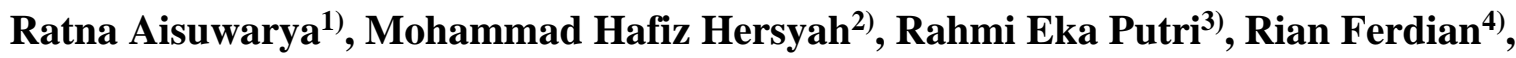 \\ Fatimah $^{5)}$
}

\author{
Jurusan Sistem Komputer, Fakultas Teknologi Informasi Universitas Andalas \\ Kampus Unand Limau Manis, Padang, Sumatera Barat, Indonesia \\ aisuwarya@fti.unand.ac.id
}

\begin{abstract}
ABSTRAK
Salah satu upaya dalam meningkatkan produktivitas sapi perah adalah dengan menerapkan manajemen pemeliharaan pada sapi perah berupa kegiatan recording atau pencatatan data ternak. Kelompok tani Lembu Alam Serambi telah memiliki sebuah sistem pencatatan dengan menggunakan kartu ternak yang disediakan oleh Dinas Peternakan. Kartu ternak yang digunakan untuk recording data sapi perah terbuat dari jenis kertas yang memiliki beberapa kelemahan yaitu, mudah hilang, robek, basah, terbakar, dan kotor. Untuk mengatasi kelemahan kartu ternak ini, diterapkan proses recording pada Android menggunakan teknologi Near Field Communication (NFC). Pada kegiatan pengabdian ini dirancang sebuah sistem implementasi teknologi NFC yang terintegrasi dengan ear tag sapi dan aplikasi android. Sistem ini digunakan untuk mengidentifikasi sapi perah dan proses recording data dengan aplikasi berbasis android. Pada sistem recording data sapi ini terdiri dari dua buah aplikasi mobile, yaitu aplikasi rekam data sapi dan aplikasi tap tag NFC. Melalui aplikasi rekam data sapi akan ditampilkan halaman untuk mendaftarkan NFC tag sebagai identifier ear tag sapi. Pada aplikasi tap tag NFC akan menampilkan data sapi yang telah disimpan di database firebase. Berdasarkan hasil implementasi sistem yang telah dilakukan dapat disimpulkan bahwa kegiatan pengabdian masyarakat yang telah dilakukan dapat membantu memudahkan Kelompok Tani Lembu Alam Serambi dalam melakukan proses recording data sapi perah.
\end{abstract}

Kata kunci: NFC, Recording, Sapi

\section{ABSTRACT}

One of the efforts in increasing the productivity of dairy cows is to apply maintenance management to dairy cows in the form of recording livestock data. Lembu Alam Serambi farmer group has a recording system using livestock cards provided by the Animal Husbandry Department. Cattle cards used for data recording of dairy cows are made from a type of paper that has several disadvantages, namely, easily lost, torn, wet, burned, and dirty. Therefore, to overcome this problem, we apply Android using Near Field Communication (NFC) technology. In this community service, the NFC technology implementation system is integrated with cow's ear tag and android application. This system is used to identify dairy cows and process data recording with an Android-based application. In this cow data recording system consists of two mobile apps, namely cow data record application and NFC tap tag application. The system implementation shows that the community service activity can help facilitate the Lembu Alam Serambi farmer group in the process of recording dairy cattle data.

Keywords: NFC, Recording, Cattle

\section{Pendahuluan}

Salah satu upaya dalam meningkatkan produktivitas sapi perah adalah dengan menerapkan manajemen pemeliharaan pada sapi perah berupa kegiatan recording atau pencatatan data ternak, (Murfiani, Fini, 2018). Recording merupakan suatu kegiatan mendokumentasikan pencatatan kejadian-kejadian dan informasi penting yang menyangkut sapi perah. Recording sangat penting 
dilakukan sebagai landasan dasar untuk mengambil keputusan yang tepat dalam kebijakan peternakan. Dari hasil recording tersebut maka dapat dilakukan program pembibitan sapi perah melalui seleksi terhadap pedet, calon induk dan calon penjantan unggul yang akan digunakan sebagai replacement stock, sedangkan sisanya dapat diperah, (Singosari, 2006).

Pemilihan lokasi di Kelompok Tani Lembu Alam Serambi disebabkan karena kelompok tani ini menghasilkan produk susu yang sudah rutin dalam beberapa tahun terakhir. Kelompok tani ini juga telah memiliki sebuah sistem pencatatan yang berkaitan dengan data ternak sapi. Sistem pencatatan tersebut dengan menggunakan kartu ternak yang disediakan oleh Dinas Peternakan.

Kartu ternak yang digunakan untuk recording data sapi perah terbuat dari jenis kertas. Sistem pencatatan ini memiliki beberapa kelemahan yaitu, mudah hilang, robek, basah, terbakar, dan kotor. Kelompok Tani Lembu Alam Serambi memiliki beberapa ekor sapi perah sehingga dibutuhkan kartu sapi sesuai dengan banyaknya jumlah sapi. Setiap sapi memiliki kartu tersendiri sehingga memerlukan waktu menemukan kartu sesuai dengan identitas sapi tersebut. Sehingga diperlukan sebuah aplikasi yang dapat memudahkan dalam proses kegiatan recording data sapi perah. Untuk mengatasi kelemahan kartu ternak ini, diterapkan proses recording pada Android menggunakan teknologi Near Field Communication (NFC).

Kegiatan pengabdian kepada masyarakat yang telah dilakukan sebelumnya, sistem recording data sapi menggunakan teknologi Radio Frequency Identification (RFID), (Aisuwarya, R, dkk, 2019). Pada sistem ini pembacaan tag RFID menggunakan RFID reader yang di baca menggunakan mikrokontroler Arduino Uno dan hasil pembacaan ID RFID ditampilkan pada LCD. Kelemahan sistem ini adalah hasil pembacaan data-data sapi di tidak ditampilkan di smartphone tapi di cetak. Sehingga fungsi smartphone hanya untuk menginputkan data saja. Kemudian, sistem ini juga belum terintegrasi dengan ear tag sapi, yang mana data ear tag sapi sangat penting bagi sebuah peternakan. Ear tag berisi tahun lahir dan nomor individu hewan sebagai tanda untuk menghindari terjadinya perkawinan sesama ras.

Berdasarkan latar belakang di atas dan pengabdian sebelumnya, terlihat betapa pentingnya suatu sistem recording sapi yang menggunakan ear tag sapi sebagai ID sapi. Pada kegiatan pengabdian ini dirancang sebuah sistem yang mengembangkan sistem yang telah dibuat sebelumnya, yaitu implementasi teknologi NFC yang terintegrasi ear tag sapi dan aplikasi android. Sistem ini digunakan untuk mengidentifikasi sapi perah dan pengenalan aplikasi berbasis android dalam proses recording sapi perah di Kelompok Tani Lembu Alam Serambi, Kota Padang Panjang. Sehingga dapat membantu memudahkan Kelompok Tani Lembu Alam Serambi dalam melakukan proses recording data sapi perah lebih efektif dan efisien.

\section{Tinjauan Pustaka}

\subsection{Recording Data Ternak}

Salah satu faktor dalam manajemen peternakan adalah pencatatan atau recording. Sebuah peternakan memiliki jumlah sapi yang dikelola tidak sedikit, sehingga diperlukan pencatatan atau recording mengenai hewan ternak tersebut, (Soni, Basya, 2013). Recording adalah segala sesuatu yang berhubungan dengan pencatatan hewan ternak yang menunjukkan pertumbuhan dan perkembangan hewan ternak.

Dalam proses recording data ternak dibutuhkan sebuah pencatatan yang memuat data-data yang diperlukan sebagai dasar analisa. Pengumpulan data sapi ternak dilakukan dengan pencatatan pada kartu ternak sapi (gambar 1). Kelompok Tani Lembu Alam Serambi menggunakan dua kartu ternak sapi sesuai dengan instruksi Dinas Pertanian UPTD Pusat Kesehatan Hewan Padang Panjang yaitu:

1. Kartu kelahiran sapi.

Kartu kelahiran sapi ini digunakan untuk pencatatan data identitas sapi seperti tanggal lahir, jenis kelamin, kondisi dan nama petugas.

2. Kartu Akseptor Inseminasi Buatan. 
Kartu pencatatan ini digunakan untuk mencatat data informasi inseminasi pada sapi perah.

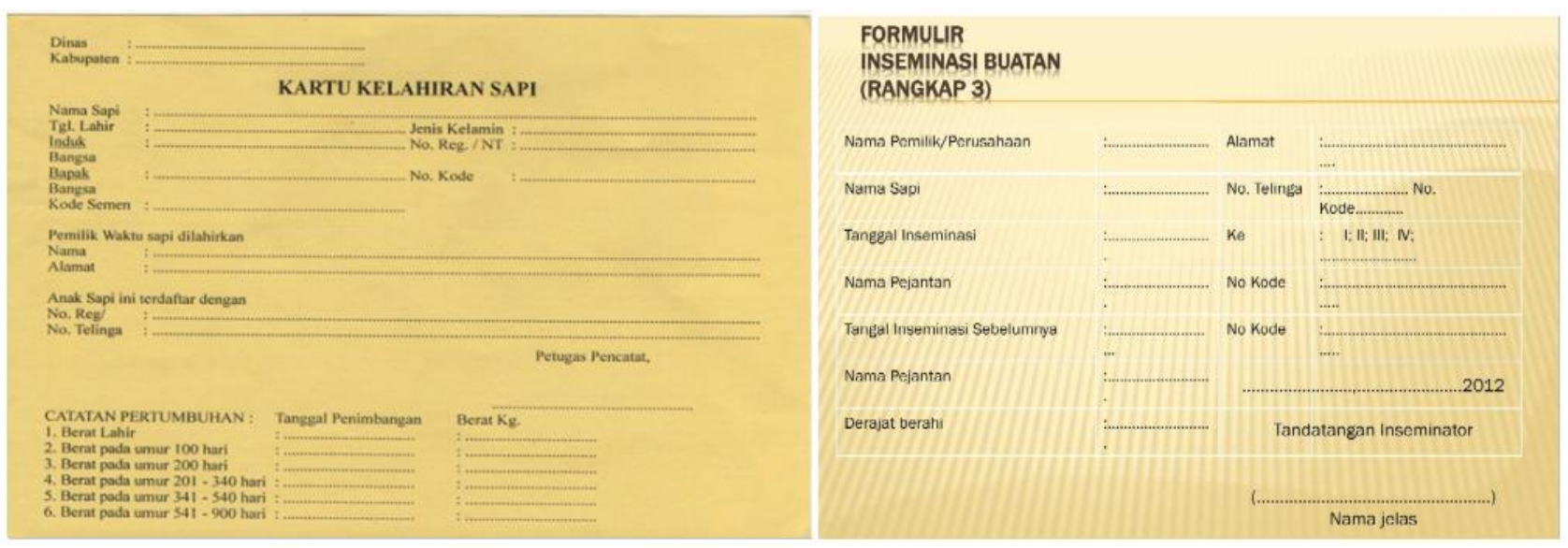

Gambar 1. Kartu Ternak Sapi

\subsection{Ear Tag Sapi}

Ear tag adalah sejenis anting yang memiliki kode tertentu berupa angka ataupun huruf berfungsi sebagai tanda pengenal sapi. Ear tag biasanya dipasang di daun telinga sapi karena telinga sapi merupakan bagian yang paling lunak untuk dipasang atau ditusuk dengan jarum dan merupakan bagian yang mudah dilihat. Pemasangan Ear tag biasanya pada telinga sebelah kiri. Pemasangan Ear tag ini dilakukan saat sapi masih berusia muda (pedet) yaitu usia 0 bulan sampai 8 bulan. Pemasangan pada pedet ini bertujuan untuk memperkecil kemungkinan sapi stres.

Penomoran pada ear tag sapi ini terdiri dari tiga buah angka. Angka-angka ini menunjukkan tahun kelahiran dan nomor individu sapi. Seperti pada gambar 2, angka tiga menunjukkan tahun kelahiran sapi yaitu tahun 2003 dan angka 12 menunjukkan nomor terdaftar hewan individu.

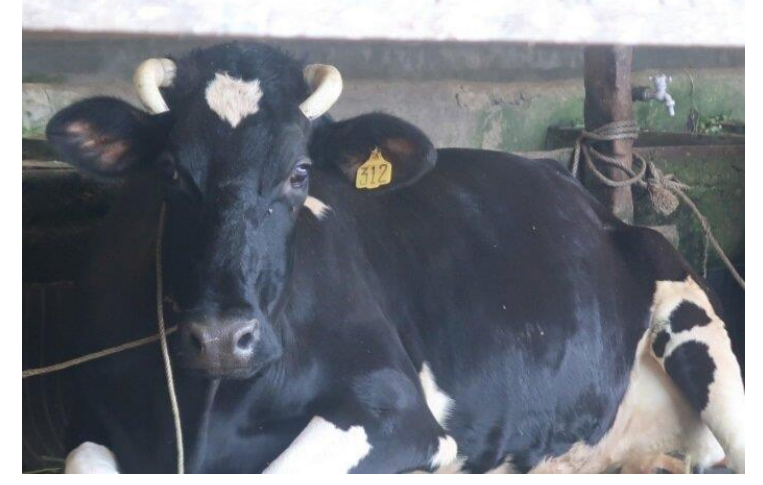

Gambar 2.Ear Tag Sapi

\subsection{Near Field Communication (NFC)}

Near Field Communication (NFC) adalah seperangkat teknologi konektivitas nirkabel berbasis teknologi Radio Frequency Identification (RFID). NFC ini menggunakan induksi medan magnet untuk memungkinkan komunikasi antar perangkat elektronik yang mengandung NFC tag (gambar 3) dalam jarak yang dekat, (Pardede, Jasman. dkk. 2014). Dalam melakukan transfer data NFC memiliki jarak maksimal $10 \mathrm{~cm}$ dan kecepatan transfernya mulai dari $106 \mathrm{kbit} / \mathrm{s}, 212 \mathrm{kbit} / \mathrm{s}$, dan 424 kbit/s. Teknologi NFC bekerja dengan sistem transmisi sinyal radio jarak pendek. Pada teknologi NFC terdapat dua perangkat, perangkat tag dan perangkat reader, (Proehl, Greg. 2020). 


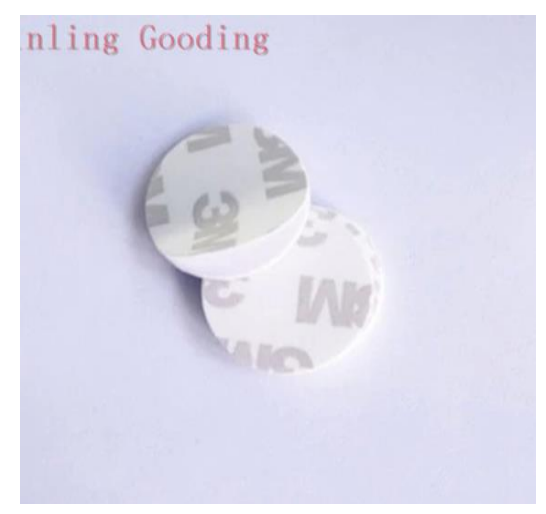

Gambar 3. NFC Tag

\section{Metodologi Penelitian}

\subsection{Rancangan Umum Sistem}

Gambar 4 berikut merupakan arsitektur rancangan sistem recording data ternak sapi yang akan dibuat untuk Kelompok Tani Lembu Alam Serambi Kota Padang Panjang :

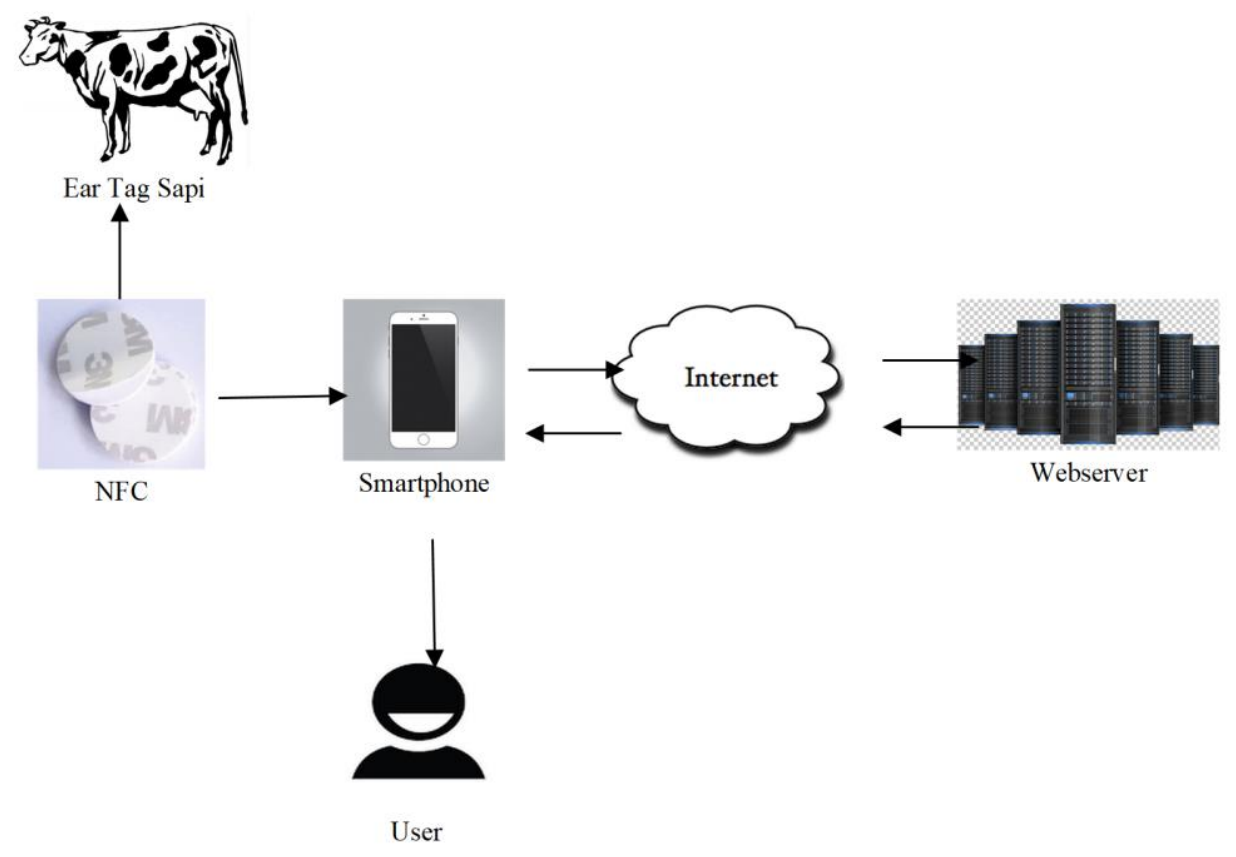

Gambar 4. Rancangan Sistem

Ear Tag berfungsi sebagai pengenal sapi, yang terdiri dari tiga buah angka yang terdiri tahun kelahiran dan nomor individu sapi. Pada ear tag kemudian dipasangkan NFC Tag, yang berfungsi untuk mengidentifikasi setiap sapi. Selanjutnya, Smartphone Android akan membaca NFC Tag untuk melakukan penambahan data baru, mengirim data ke database pada web server dan menampilkan hasil data recording sapi ternak.

\subsection{Rancangan Proses dan Use Case Diagram}

Berdasarkan rancangan sistem, terdapat dua aplikasi yang digunakan oleh peternak sapi, yaitu aplikasi rekam data sapi dan aplikasi tap tag NFC. Aplikasi rekam data sapi berfungsi untuk membaca ID NFC sapi dan menginputkan data sapi. Sedangkan aplikasi tap tag NFC untuk membaca data-data sapi yang telah tersimpan. Dapat dilihat pada gambar 5 sebagai berikut. 


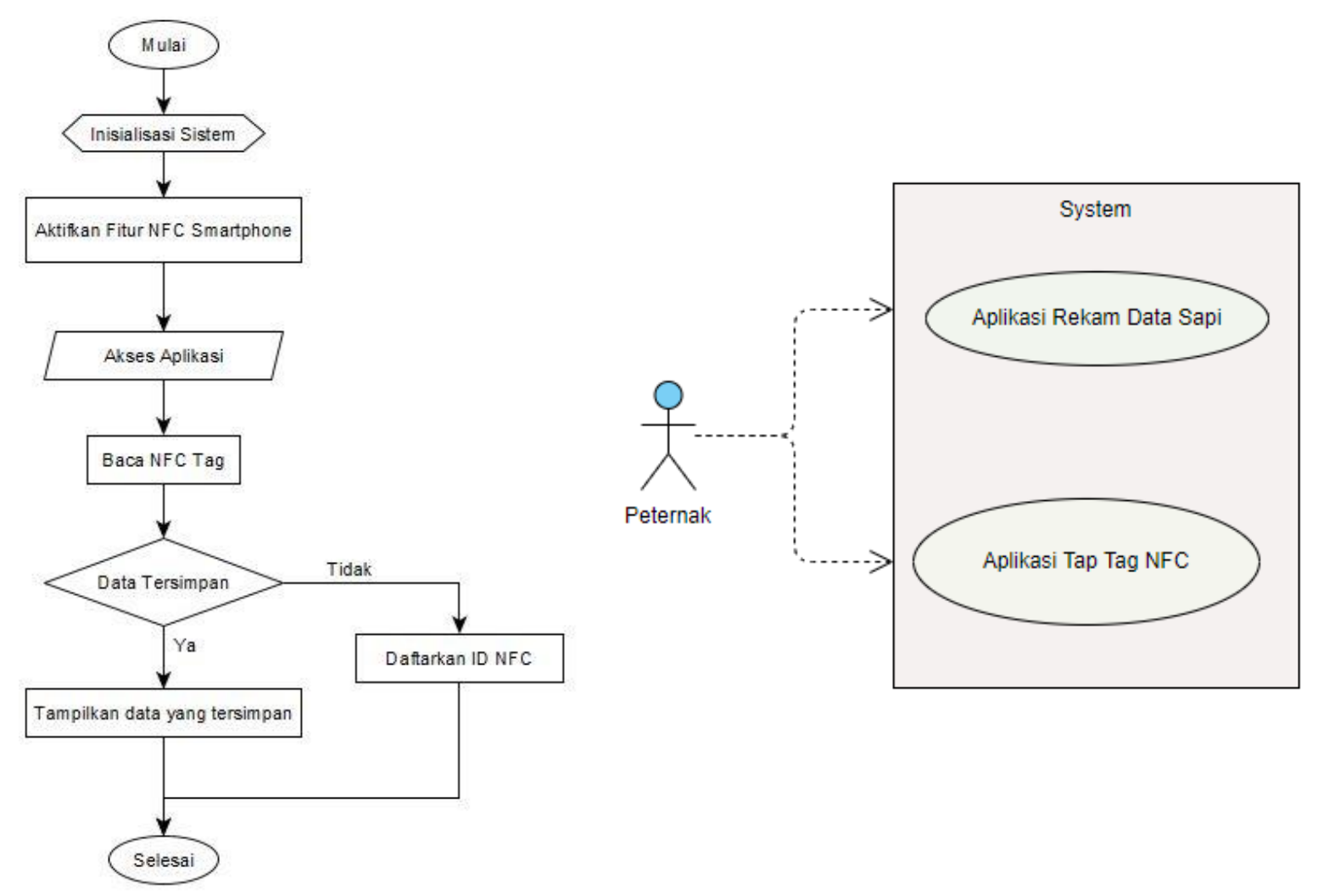

Gambar 5. Rancangan Proses dan Use Case Diagram

\section{Hasil dan Pembahasan}

\subsection{Implementasi Sistem}

Implementasi sistem ini terbagi dua bagian yaitu implementasi perangkat keras dan implementasi perangkat lunak. Gambar 6 memperlihatkan perangkat keras yang digunakan. NFC tag, sebagai identifier ear tag sapi dan smartphone, digunakan sebagai media untuk mendaftarkan, merekam dan membaca data dari NFC tag dan firebase.

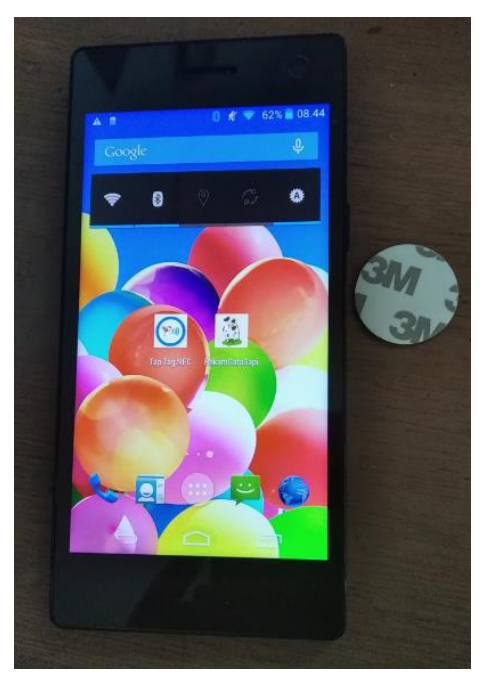

Gambar 6. Perangkat Keras Sistem

Implementasi perangkat lunak mencakup dua komponen perangkat lunak yaitu aplikasi web App Inventor sebagai pembangun aplikasi mobile dan firebase, yang digunakan untuk menyimpan 
data secara realtime. Pada sistem recording data sapi ini terdiri dari dua buah aplikasi mobile, yaitu aplikasi rekam data sapi dan aplikasi tap tag NFC. Melalui aplikasi rekam data sapi akan ditampilkan halaman untuk mendaftarkan NFC Tag sebagai identifier ear tag sapi. Pada aplikasi tap tag NFC akan menampilkan data sapi yang telah disimpan di firebase. Implementasi aplikasi mobile dapat dilihat pada gambar 7 berikut (a). Aplikasi Rekam Data sapi, (b). Aplikasi Tap Tag NFC. Data-data yang diinputkan adalah ID NFC, no telinga, ras sapi, kode bibit, tanggal inseminasi, tanggal periksa inseminasi, hasil inseminasi, tanggal kelahiran dan jenis kelamin.
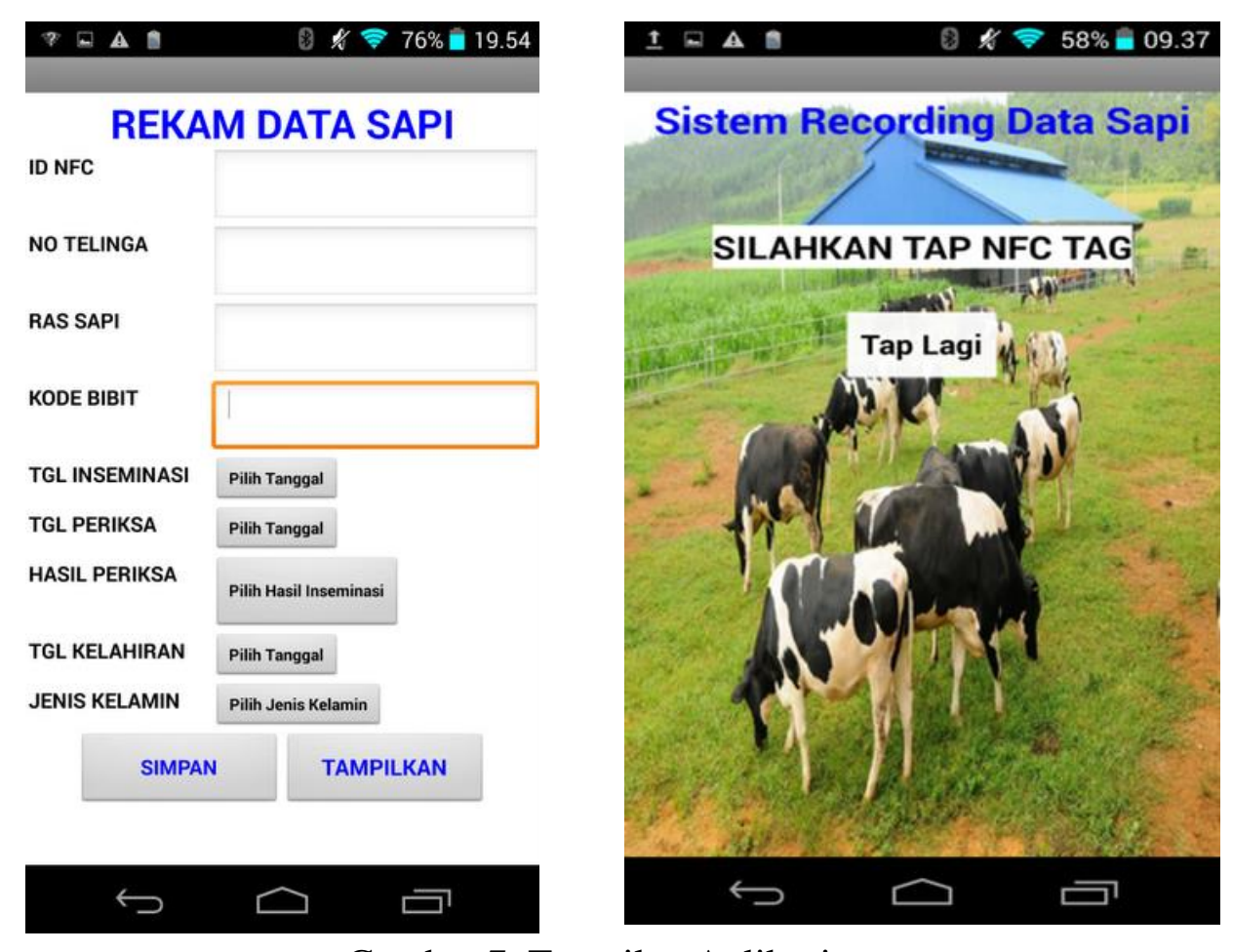

Gambar 7. Tampilan Aplikasi

\subsection{Pembahasan dan Evaluasi}

Sistem yang telah dirancang dan diuji coba kemudian akan diimplementasikan langsung pada peternakan sapi milik kelompok tani lembu alam kota Padang Panjang. Setiap sapi yang ada pada peternakan akan dipasangkan sebuah NFC tag, dengan cara ditempelkan pada ear tag sapi yang sudah terpasang di telinga masing-masing sapi tersebut (gambar 8).
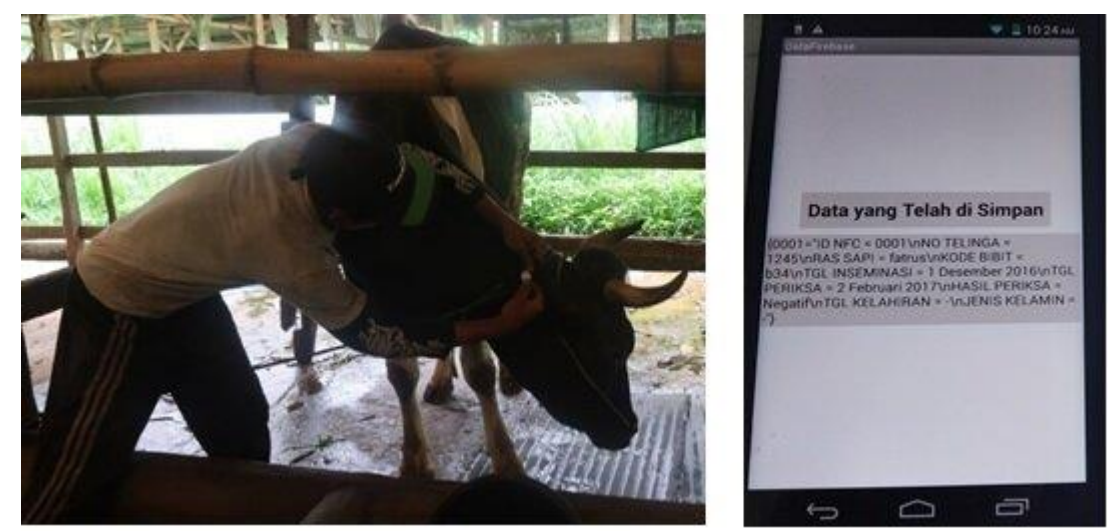

Gambar 8. Pemasangan Tag dan Tampilan Data Sapi

Setelah dilakukan pemasangan NFC Tag dilakukan pengujian mengunakan smartphone. Pengujian ini dilakukan bertujuan untuk mengetahui jarak minimum dan maksimum yang bisa dideteksi oleh smartphone terhadap NFC Tag. Pengujian dilakukan dengan mendekatkan bagian 
belakang smartphone ke NFC Tag yang ditempelkan di ear tag di telinga sapi. Tabel 1 berikut menunjukan hasil pengujian tersebut :

Tabel 1. Pengujian NFC Tag dan Smartphone

\begin{tabular}{ccccc}
\hline No & Jarak $(\mathrm{cm})$ & Pengujian 1 & Pengujian 2 & Pengujian 3 \\
\hline 1. & 0 & Terdeteksi & Terdeteksi & Terdeteksi \\
2. & 0,5 & Terdeteksi & Terdeteksi & Terdeteksi \\
3. & 1,0 & Terdeteksi & Terdeteksi & Terdeteksi \\
4. & 1,5 & Terdeteksi & Terdeteksi & Terdeteksi \\
5. & 2,0 & Tidak terdeteksi & Tidak terdeteksi & Tidak terdeteksi \\
6. & 2,5 & Tidak terdeteksi & Tidak terdeteksi & Tidak terdeteksi \\
\hline
\end{tabular}

Berdasarkan pengujian yang telah dilakukan diatas, jarak NFC tag yang dapat dideteksi oleh smartphone adalah antara jarak $0 \mathrm{~cm}$ sampai dengan $1.5 \mathrm{~cm}$. Yang berarti NFC Tag akan terbaca dalam jarak maksimal $1.5 \mathrm{~cm}$, dan tidak akan terbaca jika jarak melebihi $1.5 \mathrm{~cm}$. Jarak pembacaan ini akan bervariasi karena setiap smartphone yang berfungsi sebagai NFC reader memiliki kepekaan baca yang berbeda. Smartphone yang digunakan untuk recording ini memiliki kepekaan baca yang rendah sehingga jarak bacanya cukup kecil. Oleh karena itu jarak maksimal deteksi adalah $1,5 \mathrm{~cm}$.

NFC tag yang baru terpasang masih belum berisi data identifier sapi sehingga perlu diinputkan secara manual terlebih dahulu ke dalam sistem menggunakan aplikasi rekam data sapi. Data recording ini nantinya akan diupdate secara berkala oleh peternak ketika sapi mengalami perubahan data inseminasi, pemeriksaan dan kelahiran.

Kemudian untuk membaca data yang sudah tersimpan, digunakan aplikasi tap NFC. Gambar menunjukkan proses pembacaan tag NFC pada telinga sapi dengan cara mendekatkan smartphone yang memiliki NFC reader. Ketika aplikasi tap tag NFC dijalankan maka sistem akan menampilkan data-data recording sapi yang telah disimpan sebelumnya (gambar 9). Data-data ini diperlukan peternak dalam melakukan tindakan berikutnya, misalnya dalam melakukan inseminasi selanjutnya.
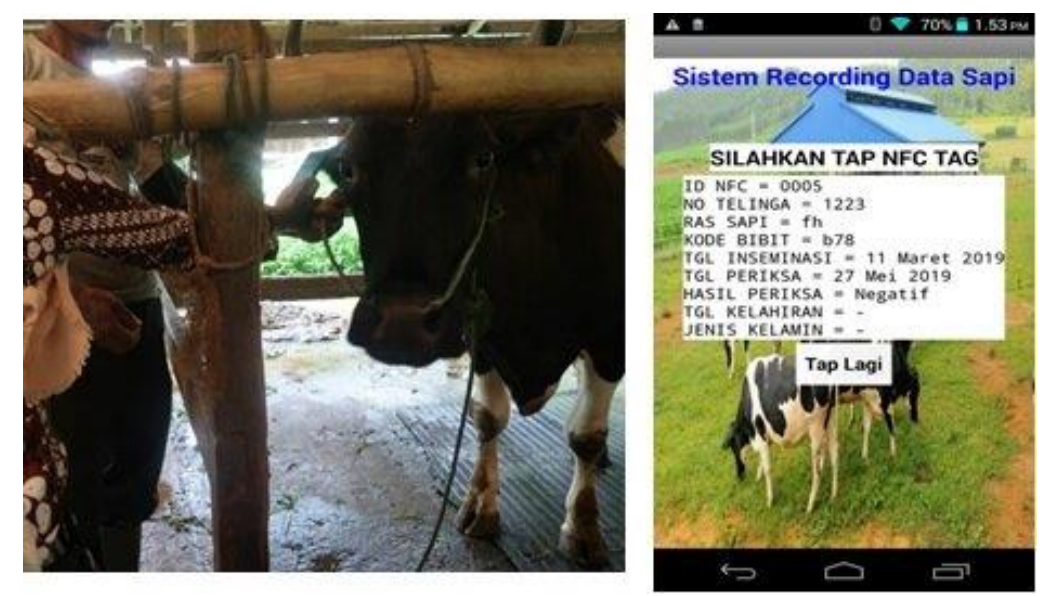

Gambar 9. Pembacaan Data Recording Sapi

Berdasarkan hasil implementasi sistem yang telah dilakukan dapat disimpulkan bahwa kegiatan pengabdian masyarakat yang telah dilakukan dapat membantu memudahkan Kelompok Tani Lembu Alam Serambi dalam melakukan proses recording data sapi perah. Sistem ini bermanfaat untuk identifikasi sapi perah dan recording data sapi perah. Untuk keberlanjutan implementasi sistem, akan dilakukan evaluasi tentang efektiitas dan daya guna dari sistem bagi Kelompok Tani Lembu 
Alam Serambi. Hasil evaluasi dan pengembangan sistem akan dilanjutkan pada tahun kedua kegiatan pengabdian masyarakat Jurusan Sistem Komputer Universitas Andalas.

\section{Daftar Pustaka}

Aisuwarya, Ratna, dkk. (2019). Implementasi Teknologi RFID (Radio Frequency Identification) Untuk Recording Data Sapi Ternak. Jurnal Hilirisasi IPTEKS, Vol.2 No.1.

Hidayat, Benny. (2017). Pengenalan Google Firebase untuk Hybrid Mobile Apps Berbasis Cordova. Jurnal Teknik Informatika, Vol.3 No.1.

Murfiani, Fini. (2018). PERMENTAN Nomor 26/2017 Dorong Pelaku Usaha Persusuan Bermitra dengan Peternak. 7 Februari 2020. http://ditjennak.pertanian.go.id/.

Pardede, Jasman. dkk. (2014). Implementasi NFC pada Aplikasi Layanan Informasi Benda Museum Berbasis Android. Jurnal informatika Jurusan Teknik Informatika Institut Teknologi Nasional, Vol.5 No. 2.

Proehl, Greg. (2020). An Introduction to Near Field Communications. 4 Maret 2020. https://www.mouser.com/applications/rfid-nfc-introduction/.

Sandy, Luffi Aditya, dkk. (2017). Rancang Bangun Aplikasi Chat pada Platform Android denagn Media Input berupa Canvas dan Shareable Canvas untuk Bekerja dalam Satu Canvas secara Online. JNTK, Vol.6 No.2.

Singosari, BBIB. (2006). Dukungan Singosari dalam Program IB di Jawa Timur dalam Seminar : Menuju Satu Setengah Juta Akseptor Sapi dalam Program Intan Sejati Jawa Timur 29 Januari 2020. Surabaya.

Soni, Basya. (2013). Bisnis Penggemukan Sapi. Jakarta : Swadaya. 